\title{
Young alcoholic patient with acute vision loss: pancreatitis-related or a marker of underlying autoimmune disease
}

\author{
Rtika R Abraham, ${ }^{1}$ Mrinal Pahwa, ${ }^{2}$ Jagpal Singh Klair, ${ }^{3}$ Mohit Girotra ${ }^{4}$
}

${ }^{1}$ Department of Geriatrics, University of Arkansas for Medical Sciences, Little Rock, Arkansas, USA

${ }^{2}$ Department of Surgery, Sir Ganga Ram Hospital, New Delhi, India

${ }^{3}$ Department of Internal Medicine, University of Arkansas for Medical Sciences, Little Rock, Arkansas, USA ${ }^{4}$ Department of

Gastroenterology, University of Arkansas for Medical Sciences, Little Rock, Arkansas, USA

\section{Correspondence to} Dr Jagpal Singh Klair, klairjagpal@yahoo.com

Accepted 9 April 2014

\section{CrossMark}

To cite: Abraham RR, Pahwa M, Klair JS, et al. BMJ Case Rep Published online: [please include Day Month Year] doi:10.1136/ bcr-2014-204949

\section{DESCRIPTION}

Purtscher's retinopathy (PR) was first described in 1910 as associated with trauma, and its association with acute pancreatitis was not described until late 1970s. A recent UK and Ireland survey by Agrawal and McKibbin ${ }^{1}$ found that acute pancreatitis is one of the most common causes of PR accounting for one-third of the cases. In PR, the typical ophthalmoscopic findings include: large infarcts in the retinal capillary bed known as Purtscher flecken, small retinal microinfarcts at the level of the nerve fibre layer known as cotton-wool spots and intraretinal haemorrhages confined to an area by the optic disc and macula ${ }^{2}$ (as seen in our patient, shown in figure 1). The pathophysiology of PR has not been fully elucidated. Evidence suggests that proteolytic enzymes released during acute pancreatitis activate the complement cascade forming C5a-induced leucocyte, platelet and fibrin aggregates that embolise to the retinal arterioles and choroid vessels subsequently damaging photoreceptors. $^{2}{ }^{3}$ Alternate theories suggest that it could be in part due to fat emboli secondary to pancreatic digestion of omental fat. Other conditions associated with PR include certain types of systemic vasculitides (such as scleroderma, systemic lupus erythematosus and dermatomyositis), lymphoproliferative disorders, bone marrow transplantation, valsalva manoeuvre and pancreatic adenocarcinoma. $^{3}$ There is no treatment for PR, however, associated conditions if any should be treated. In patients with acute necrotising pancreatitis, the development of PR has been shown to be associated with poor prognosis and may precede multiple organ failure. Overall, the visual prognosis is guarded and initially compromised vision may improve over a period of months.

\section{Learning points}

Acute pancreatitis is one of the most common causes of Purtscher's retinopathy (PR) and shown to be associated with poor prognosis and may precede multiple organ failure.

- Typical opthalmoscopic findings are pale optic discs, multiple cotton-wool spots and retinal and pre-retinal haemorrhages.

- Even though PR itself has no treatment, workup should be initiated to diagnose and treat associated conditions.

\section{Competing interests None.}

Patient consent Obtained.

Provenance and peer review Not commissioned; externally peer reviewed.

\section{REFERENCES}

1 Agrawal A, McKibbin M. Purtscher's retinopathy: epidemiology, clinical features and outcome. Br J Ophthalmol 2007:91:1456-9.

2 Jacob HS, Craddock PR, Hammerschmidt DE, et al. Complementinduced granulocyte aggregation: an unsuspected mechanism of disease. N Engl J Med 1980;302:789-94.

3 Holló G, Tarjányi M, Varga $M$, et al. Retinopathy of pancreatitis indicates multiple-organ failure and poor prognosis in severe acute pancreatitis. Acta Ophthalmol (Copenh) 1994;72:114-17.
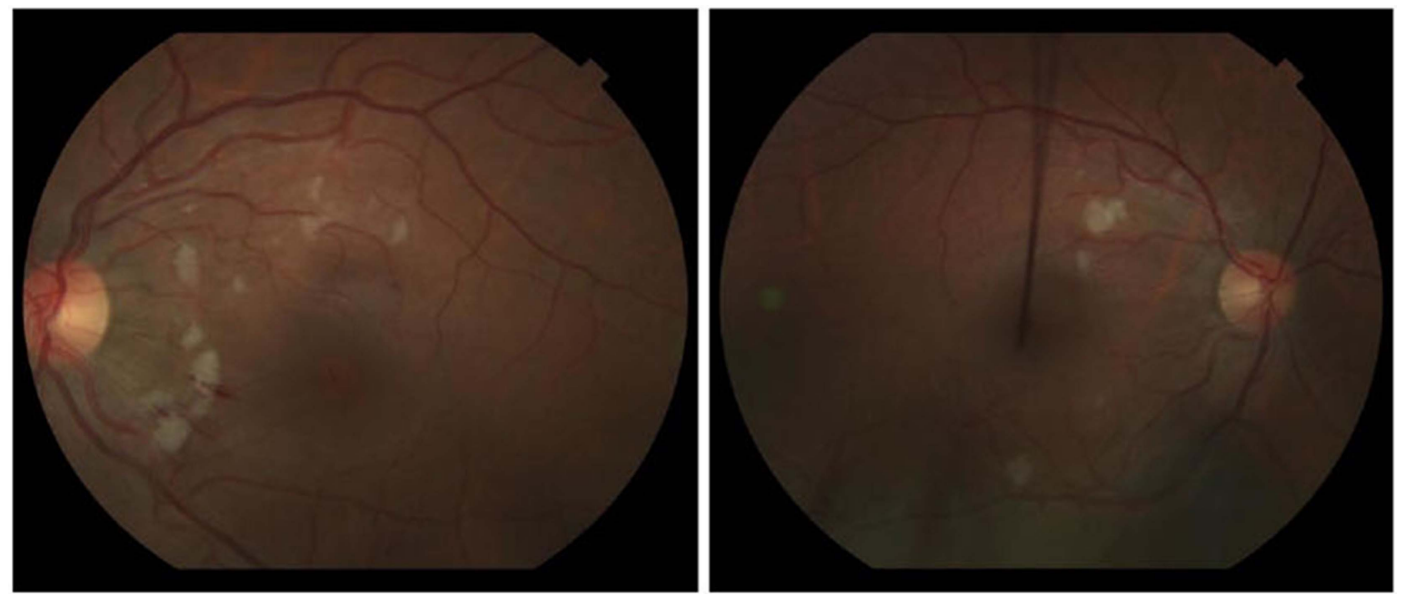

Figure 1 Pale optic discs, multiple cotton-wool spots and retinal and pre-retinal haemorrhages. 


\section{Images in...}

Copyright 2014 BMJ Publishing Group. All rights reserved. For permission to reuse any of this content visit http://group.bmj.com/group/rights-licensing/permissions.

BMJ Case Report Fellows may re-use this article for personal use and teaching without any further permission.

Become a Fellow of BMJ Case Reports today and you can:

- Submit as many cases as you like

- Enjoy fast sympathetic peer review and rapid publication of accepted articles

- Access all the published articles

- Re-use any of the published material for personal use and teaching without further permission

For information on Institutional Fellowships contact consortiasales@bmjgroup.com

Visit casereports.bmj.com for more articles like this and to become a Fellow 